\title{
The Impact of the Goods and Services Tax on Mortgage Costs: Evidence from Australian Mortgage Corporations
}

\author{
Allen Huang (Corresponding author) \\ Department of Accounting, Finance and Economics, Griffith University \\ 170 Kessels Road, Brisbane, Queensland 4111, Australia \\ Tel: 61-7-3735-7278Ｅ-mail: a.huang@griffith.edu.au \\ Benjamin Liu \\ Department of Accounting, Finance and Economics, Griffith University \\ 170 Kessels Road, Brisbane, Queensland 4111, Australia \\ E-mail: b.liu@griffith.edu.au
}

Received: October 21, 2012

Accepted: November 12, 2012

Online Published: December 16, 2012

doi:10.5430/ijfr.v4n1p54

URL: http://dx.doi.org/10.5430/ijfr.v4n1p54

\begin{abstract}
Australia has seen significant rises in mortgage costs and sharp declines in housing affordability in the past decade or so, which corresponds with the introduction of the Goods and Services Tax (GST) in July 2000. To what extent the GST has impacted mortgage costs is the research question. This study investigates the GST impact on the mortgage costs of Australian mortgage corporations. Using data of mortgage corporations operating in Australia, we perform $t$-tests and multivariate regression analysis to examine the GST effects on mortgage yield spreads. The empirical results clearly indicate that mortgage corporations increased their mortgage charges in the post-GST periods significantly beyond the magnitude of the GST. Furthermore, the lenders started to increase the yield spreads before and continued to increase the spreads after the implementation of the GST, indicating the rise in mortgage costs was not a one-off surge. The findings offer insights into mortgage costs and have significant policy implications and wider economic relevance.
\end{abstract}

Keywords: Australian GST, Mortgage loans, Mortgage costs, Housing affordability

\section{Introduction}

Australia has seen significant rises in mortgage costs and sharp declines in housing affordability in the past decade or so, which corresponds with the introduction of the Goods and Services Tax (GST) in July 2000. According to a recent survey (Demographia, 2009), Australia's housing affordability is the lowest among the surveyed countries (i.e., Australia, Canada, Ireland, New Zealand, United Kingdom and United States). Housing mortgage plays an important role in the nation's economy, quality of living and, in particular, housing affordability. The control and reduction of mortgage costs, therefore, have become an important issue in the Australian housing market, especially since the implementation of the GST. According to the Reserve Bank of Australia, the housing mortgage loans outstanding at the end of 2011 reached A $\$ 1.2$ trillion. Based on this amount, every 10 basis point rise in mortgage interest would lead to an increase of A $\$ 1.2$ billion per annum in the borrowers' cost. In addition, mortgage is the single largest asset of the financial institutions and the single largest liability of the households in Australia. An understanding of precisely what factors have contributed to the rise in mortgage costs and how the GST has affected mortgage costs is, therefore, a significant issue and a prerequisite for the regulators and policymakers to reach appropriate policy decisions. This paper empirically examines the changes of mortgage yield spreads in the pre- and post-GST periods and quantitatively measures the impact of the GST on mortgage costs in Australia. The findings of this research would provide insights into mortgage costs and should have significant policy implications and wider economic relevance. In the wake of the recent global financial crisis, the mortgage cost issue has attracted a widespread attention. Thus, the findings of this paper may also have international implications and significance. 
As a milestone in tax reform since World War II, Australia introduced a new tax system that abolished a range of indirect taxes, such as the Wholesale Sales Tax, and replaced them with a GST of 10 per cent of the selling price (Maclntyre, 2001). The new tax system, which came into effect on 1 July 2000, led to a substantial structural change in the Australian economy. Broadly speaking, the Australian GST is similar to the value added tax (VAT) operating in the UK and several other European countries. It applies to most forms of economic activities such as supplies of goods, services and other things, with exemptions for some goods and services (Bolton and Dollery, 2005). The essential policy concept of GST, like VAT, is that of value adding. This requires each business to pay GST on the value it adds to a product/service and the full cost of GST is passed on to the end-consumer. Hence, each business pays GST on the supplies it acquires (input GST) and then recovers the GST it has paid by passing it on to the customer (output GST). The input GST is treated as input tax credit (ITC) against the amount of output tax that a business charges on the supplies it makes and for which the business is liable to account. The treatment of financial institutions, however, differs from other types of organisations. First, no GST applies directly to funding and financial activities such as taking securities and deposits, issuing loans and charging interests on mortgages. In other words, no input GST is paid on the financial supplies that financial institutions acquire and no output GST is charged on the financial supplies that financial institutions provide. Second, financial institutions, similar to other types of organisations, pay GST on non-financial, operational supplies (such as office equipment and supplies) they acquire (that is, input GST). With no output GST on financial supplies, however, the input GST in the operating costs is not fully recoverable as ITC. As a consequence, financial institutions are effectively treated as the end-consumer. This input GST cost will need to be absorbed by financial institutions first and then be allocated to their customers (e.g., mortgage holders) through increasing the overall charges. For example, a lender may increase the margins or fees it charges to its customers to cover the GST costs (Maclntyre, 2001) (Note 1).

An observation on the mortgage yield spreads of mortgage corporations, a major mortgage lender in the nation, in the pre- and post-GST periods clearly shows an upward trend of the yield spreads in the post-GST period, indicating an increase in mortgage costs during that period. Based on the observation, there are three research questions to be answered: (1) Has the introduction of the GST in Australia impacted the mortgage costs charged by mortgage providers? (2) Is the GST impact a one-off surge as predicted or has it persisted? (3) To what extent did the GST contribute to the increase in mortgage costs?

Since the introduction of the GST in Australia in July 2000, a number of studies have been conducted by relevant organizations and academic researchers to examine various issues pertinent to the GST. The studies can be broadly classified into two categories. The first category of studies attempts to determine the effects of the GST on the price level of goods and services (e.g., Commonwealth Treasury, 2000; Australian Competition and Consumer Commission, 2001 and 2003; Johnson et al., 1999; Warren et al., 1999; Valadkhani and Layton; 2004; Valadkhani, 2005). The second category of studies estimates compliance costs of the GST (e.g., Commonwealth Treasury, 1998; Ernst and Young, 1999; Tran-Nam, 1999, 2000 and 2001; Buffini, 2000 a, b). While the research on price levels only provides general information with limited usefulness, the estimated implementation costs of the GST in the literature are based on different assumptions, using different survey techniques with varying sample sizes and lumping the GST-related and normal upgrading computer and system costs together. Consequently, Tran-Nam (2000) concludes that those estimates are either baseless or difficult to justify.

In a period of nearly ten years after the implementation of the GST, there had been no research into the GST impact on mortgage costs. Only in recent years did the current authors start investigating this important issue. Huang and Liu (2012) examine the GST impact on Australian banks' mortgage costs. Liu and Huang $(2010,2011,2012)$ document the GST impact on mortgage costs of non-bank and not-for-profit financial institutions, i.e., building societies and credit unions, in Australia.

To date, the GST impact on mortgage interests charged by mortgage corporations has not been investigated. Given the fact that mortgage corporations, as non-bank and profit-oriented financial institutions, are specialized in the mortgage lending market in the nation and play an important role in this market, there is a need that this impact be investigated and documented. To fill this gap in the literature and to answer the questions raised above, we collected the monthly mortgage data of Australian major mortgage corporations over 36 consecutive months from January 1999 to December 2001, covering 18 months before and 18 months after the implementation of the GST on 1 July 2000. This results in a total of 1344 observations. We then employ $t$-tests and multivariate regression models to test the mortgage data and relating variables, including the introduction of the GST, credit criteria, market condition variables and seasonal effects. 
The main findings of this study are that the introduction of the GST in July 2000 has contributed to significant rises in mortgage costs charged by mortgage corporations in the post-GST periods. Furthermore, contrary to common understanding, the GST impact on mortgage costs was not just a one-off surge taking place in the third quarter of 2000 when GST was implemented. In fact, mortgage yield spreads of mortgage corporations started to rise significantly in the first and second quarters of 2000, two quarters before the implementation of the GST. Mortgage costs continued to rise after the implementation of the GST. In the 6 post-GST quarters investigated, mortgage spreads were on the rise in most quarters, clearly indicating the GST impact on mortgage costs persisted. The findings provide empirical evidence that shows the GST and the treatment of the GST costs by mortgage corporations have significantly increased the mortgage costs, which are eventually borne by the Australian home loan borrowers. This increase in mortgage costs has inevitably made a contribution to the decline in housing affordability across Australia. The findings should have important financial, economic and policy implications for the regulators, policymakers, borrowers and financial intermediaries.

The rest of the paper is organized as follows. Section 2 reviews the relevant literature. Section 3 discusses data, and defines models and variables used for analysis. Section 4 presents the results while Section 5 provides concluding remarks.

\section{Literature Review}

\subsection{The GST Effects on Price Levels}

The impact of the GST on the price of goods and services (i.e., the inflationary effect) has been a concern to the Governments and other organizations. The Commonwealth Treasury and various State Treasuries have been involved in estimating or measuring the inflationary effect of the GST through the use of survey methods. The consensus of these government estimates and surveys is that the GST's effect on the goods and services included in the consumer price index (CPI) is a one-off price-perturbation in the quarter of the introduction of the GST and the magnitude of the effect varies within a small range. For example, the Commonwealth Treasury estimated that the GST could increase the overall CPI by 2.75 per cent in July 2000 (Commonwealth Treasury, 2000, p. 11). The Queensland Treasury (2001, p. 1) and New South Wales Treasury (2001, p. 14) also believed that the GST impact would be one-off event, and estimated the numerical effect to be 2.75 per cent and within $2.50-3.00$ per cent, respectively.

During the GST transition period, the Australian Competition and Consumer Commission (ACCC) conducted eight general surveys (December 1999-January 2000; March, May, August and October 2000; and February and May 2001), in which prices for various goods and services were collected from approximately 10,000 retail outlets in 115 geographical locations (i.e., major capital cities, regional cities and towns across Australia). According to the ACCC (2001, p. 2), the inflationary impact of the GST during the third and fourth quarters of 2000 was estimated to be approximately 4 per cent, with 3.7 per cent occurring in the third quarter.

Individual researchers have also endeavoured to study the effect of GST on the price level. Before the introduction of GST, Johnson et al. (1999) and Warren et al. (1999) thoroughly evaluated the revenue, efficiency and equity effects of the tax changes associated with the government's tax package. Warren et al. (1999) also predicted the possible effect of the implementation of the GST on inflation and estimated, under different assumptions, that this effect was likely to be between 0.8 and 3.6 per cent in July 2000 .

In a study of more academic nature, Valadkhani and Layton (2004) examined the magnitude and duration of the GST effect on the overall rate of inflation. Using intervention analysis (an autoregressive integrated moving average model with dummy variables), Valadkhani and Layton (2004) found that the GST effect on inflation was only temporary (i.e., in the quarter when the GST was introduced) and the size of the effect was 2.8 per cent. In another study, Valadkhani (2005), using the same methodology, investigates the price changes of goods and services in the four quarters before and four quarters after the third quarter of 2000 when the GST was implemented. Valadkhani found that the overall effect was a one-off lift in inflation of approximately 3 per cent in the third quarter of 2000 and prices did not increase significantly before or after the third quarter of 2000.

\subsection{The Tax Compliance Costs}

Other studies have focused on estimating the compliance costs of the GST. According to Tran-Nam (1999 and 2000) and others (e.g., Sandford et al., 1989), the introduction of a new tax (such as the GST) gives rise to two new types of costs: the implementation compliance costs and the recurrent compliance costs. The implementation compliance costs (hereafter, the implementation costs), alternatively referred to as commencement or start-up costs, were the costs incurred in complying with the GST when it was implemented and included mainly the administrative costs 
and the compliance costs of the implementation of the GST. The administrative costs refer to the start-up costs incurred by the Australian Taxation Office (ATO) and other regulatory bodies.

The compliance costs of implementing the GST refer to the resources expended by the economy in its preparation to comply with the GST. A broad-based tax such as the GST affects all sectors of the economy including households, firms and the budget sector (government departments, universities etc.). Most of these costs would eventually be passed on to consumers. As the compliance costs of implementing the GST are far greater than the administrative costs, research interest has been focused on the implementation costs. Around the time when the GST was introduced, there was much public interest in and concerns for the implementation costs of the GST. A wide range of estimates were made and reported. For example, the Federal Government stated in its original Regulation Impact Statement (RIS) that "start-up costs are likely to be one-off expenses and to be lower than the full year compliance costs of the GST" (Commonwealth Treasury, 1998, p. 5). In the revised RIS the Government was more explicit in stating that it expected the estimated implementation compliance costs would not exceed A $\$ 2.2$ billion (Joint Government Advocate, 2000, p. 9). Various professional organizations have assessed much higher estimates than the Government. For example, the National Tax and Accountants' Association proposed in early 1999 an estimate of at least $\$ 15$ billion. Ernst and Young (1999), based on a survey of over 320 of Australia's largest corporations, estimated that implementation compliance costs were between 0.75 per cent and 1 per cent of business' annual revenue. A later Ernst and Young report, commissioned by the NSW State Government and based on four cases of small business, suggested that the start-up cost could range from $\$ 9,750$ to $\$ 19,930$ per small firm. Using an average figure, this implies total start-up costs of at least $\$ 10$ billion for the small business sector alone (Buffini, 2000b).

The estimated implementation costs of the GST reviewed above are based on different assumptions, using different survey techniques with varying sample sizes and lumping the GST-related and normal upgrading computer and system costs together. According to Tran-Nam (2000), these estimates are either baseless or difficult to justify.

In summary, prior studies reviewed above all suggest that the GST effect on prices and the GST compliance costs are substantial, which inevitably increases costs to both businesses and consumers. However, these studies generally remain at the level of estimating either the general price effect or the overall compliance costs in the society, which renders limited contribution to our understanding of the effect and consequences brought about by the GST. In addition, these studies generally suffer from a lack of rigour in the research design, data and methodology.

\subsection{The GST Effects on Mortgage Costs}

Not until the recent years did the issue of the GST effects on mortgage costs catch the attention of researchers. Given the significance of the mortgage cost concern and the unique treatment of the GST for financial institutions and financial supplies, the current authors investigated the GST impact on the mortgage costs of Australian banks (Huang and Liu, 2012) and non-bank and not-for-profit building societies (Liu and Huang, 2010, 2011) and credit unions (Liu and Huang, 2012). The main findings of these studies are that Australian banks, building societies and credit unions all increased their mortgage charges significantly in the post-GST periods and the rise in mortgage charges was not just a one-off impact in the quarter when the GST was implemented, contrary to common understanding.

\section{Data and Methodology}

\subsection{Data (Note 2)}

The data for analysis is extracted mainly from the Cannex's monthly survey of Australian lenders, which includes monthly information on mortgage interest rates, mortgage fees and charges, credit criteria and other data, and from the Statistics of the RBA. The time periods selected for the analysis cover 36 consecutive months from January 1999 to December 2001 (that is, 18 months before and 18 months after the GST came into effect on 1 July 2000). The selection of the time periods is mainly determined by the key research question this study addresses, that is, the impact of the introduction of GST on mortgage costs. Hence, inclusion of the even pre- and post-GST periods in the analysis would allow comparisons to be made on the mortgage costs before and after the implementation of the GST. In addition, during the research period there was no significant market-wide event that could have caused abrupt alterations in the Australian mortgage market, which would lead to a more reliable outcome.

All 38 mortgage corporations operating in the mortgage market during the period are included in the analysis and are listed in appendix 1 . The data selection results in a total of 1344 monthly observations. To make the comparisons between the pre- and post-GST periods more valid, only the standard products of residential mortgages, that is, the owner-occupied home loans with adjustable interest rates (with which about 80 per cent of Australian home loans are originated), are examined. Loans for other purposes are not used. 


\subsection{Variables and Model Specification}

We use both the nominal interest rate and the annualized average percentage rate (AAPR); the latter includes the nominal rate and all other fees and charges (e.g., upfront fees for documentation, valuation and application, and ongoing service fees) levied on mortgages, that is, the effective rate). The AAPR adopted in this paper is computed using the standard calculations required under the Australian Uniform Consumer Credit Code (UCCC) and is considered to be a benchmark for comparing mortgage products in Australia (Note 3). When analysing and comparing mortgage costs, however, we use mortgage yield spreads, rather than the interest rates (either the nominal rate or the effective rate). Two types of mortgage yield spreads are derived from the nominal and effective rates: the nominal yield spreads and the effective yield spreads. The nominal yield spreads are the differences between the standard adjustable nominal rates and the 90-day bank bill rates and the effective yield spreads are the differences between the AAPR rates and the 90-day bank bill rates. The 90-day bank bill rates are often used as the benchmark in the banking industry that measures relative or margin costs and the data is collected from the RBA's Statistics.

The use of yield spreads is a standard approach in measuring mortgage costs as it helps overcome the impact of inflation and adjustments of monetary policy over time on the interest rates. This approach is, therefore, used by the RBA, the banking industry, and most mortgage pricing research (e.g., Black et al., 1981; Kumar and Ralston, 1999; Ambrose et al., 2004; Liu and Skully, 2005, 2008).

Other variables used in our analysis include the introduction of the GST as a dummy variable, the credit criteria variables (that is, loan to value ratios and maximum loan amounts), a market condition variable and the monthly and quarterly effect variables. Definitions of the variables and their predicted signs are provided in table 1.

To answer the three research questions, first, we employ $t$-tests to compare the means of mortgage yield spreads on quarterly data (there are 12 quarters from the beginning of 1999 to the end of 2001) and, more specifically, to compare the two grand means of the yield spreads before and after the introduction of GST. The $t$-tests are performed separately on the nominal and effective yield spreads. Second, we develop two pooled cross-sectional regression models to examine the GST effects on the nominal and effective yield spreads, using monthly data (see equations 1 and 2 below). Similar methodology can be found in mortgage pricing literature (e.g., Hendershott and Shilling, 1989; Ambrose et al., 2004; Liu and Skully, 2005).

$$
\begin{aligned}
& \mathrm{NYSP}_{\mathrm{i}}=\left\{\alpha_{0}+\alpha_{l} \mathrm{GST}_{\mathrm{i}}+\alpha_{2} \text { MAXLTV95 }_{\mathrm{i}}+\alpha_{3} \text { MAXLTV90 }_{\mathrm{i}}+\alpha_{4} \text { MAXLTV85 }_{\mathrm{i}}+\alpha_{5} \text { MAXLOAN200 }_{\mathrm{i}}\right.
\end{aligned}
$$

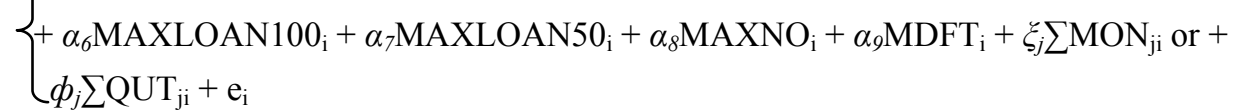

$$
\begin{aligned}
& \text { EYSP }_{\mathrm{i}}=\left\{\beta_{0}+\beta_{1} \mathrm{GST}_{\mathrm{i}}+\beta_{2} \text { MAXLTV95 }_{\mathrm{i}}+\beta_{3} \text { MAXLTV90 }_{\mathrm{i}}+\beta_{4} \text { MAXLTV85 }_{\mathrm{i}}+\beta_{5} \text { MAXLOAN200 }_{\mathrm{i}}\right.
\end{aligned}
$$

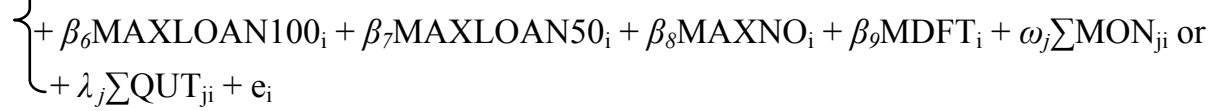

In the regression model, the dependent variable is either the nominal yield spreads (NYSP) or the effective yield spreads (EYSP). The independent variables are the GST, credit criteria, market default risk and seasonal effects (see table 1 for definition and predicted signs of the variables). As on 1 July 2000 the GST was implemented, a difference on mortgage costs (more specifically, an increase in mortgage costs) between the pre- and post-GST periods was expected. In the regression model, therefore, a dummy variable for the GST is included, with the pre-GST date with a value of 0 and otherwise 1 (see Table 1).

With respect to the credit criteria, previous studies (e.g., Hendershott and Shilling, 1989; Ambrose et al., 2004; Kau, 2005; Ebrahim and Mathur, 2007) have used loan-to-value ratios (LTV) and loan size in testing models for credit risk of mortgages. LTV ratios and loan size in the US are considered as two key factors in defining whether a loan is conforming or non-conforming. In this paper, we adopt a similar approach using both LTV ratios and loan size to measure credit risk of mortgages. LTV ratios are divided into three categories (i.e., maximum LTV $>90 \%, 90 \% \geq$ maximum LTV $\geq 85 \%$, and maximum LTV $<85 \%$ ), while maximum loan sizes are divided into four groups (see table 1), following a similar classification used by Liu and Skully (2005). As loans with higher LTV ratios are considered to bear higher credit risk (see, Ambrose et al., 2004; Liu and Skully, 2005), a positive relation is expected between the yield spreads and LTV ratios. Similarly, as larger loans are considered to have higher risk, a positive relation is also expected between the yield spreads and the loan size.

In addition, the market default risk is proxied by the yield differences between AAA- and A-rated corporate bonds with a 2-4 year constant maturity, which has also been used by prior studies (see, Black et al., 1981; Kolari et al., 
1998; Ambrose et al., 2004; Liu and Skully, 2005). A positive relation is expected between the market default premium and the mortgage yield spreads. In the model, individual months and quarters are included to examine seasonal effects, similar to the approach of prior studies (see discussion in Ambrose et al., 2004).

\section{Empirical Results}

\subsection{Results of T-test}

Quarterly means of both nominal and effective yield spreads of mortgage corporations are used to perform the $t$-tests. Later quarter average yield spreads are each compared with (deduct) earlier quarter average yield spreads using the nominal data and the effective data. The comparisons result in a matrix of $t$-tests for each of the two sets of tests, that is, mortgage corporation nominal/effective yield spread differentials, which are expressed in percentage points and are comparable to annualized interest rates.

The matrixes of $t$-tests are presented in table 2 (the nominal yield spread differentials) and table 3 (the effective yield spread differentials). In the tables, a positive figure means an increase in the yield spreads while a negative one (figures in parentheses) represents a decrease in the yield spreads.

Tables 2 and 3 show the following results. Comparing the third quarter (Q hereafter) of 2000 (the GST was implemented at the beginning of this quarter) to Q2 of 2000, there are only minimal increases in the yield spreads (11.6 basis points for the nominal and 5.3 basis points for the effective rates, both insignificant). When using the yield spreads in Q2 of 2000 as the base quarter and comparing all later quarters to the base quarter, we find that all the yield spread differentials (except for Q3 of 2000) rose substantially (all significant at $p<0.01$ ). More interestingly, except for one quarter (Q3 of 2001), four (three) out of five quarters after Q3 of 2000 recorded increases in the yield spreads for the nominal (effective) rates, indicating that mortgage yield spreads continued to rise after the implementation of the GST in Q3 of 2000. This is a strong indication that the rise in mortgage costs persisted in the post-GST periods. Furthermore, mortgage corporations' nominal and effective yield spreads started to rise in Q1 of 2000, two quarters prior to the introduction of the GST. In tables 2 and 3, a comparison of Q1 and Q2 of 2000 to Q4 of 1999 shows the nominal (effective) yield spreads rose 27.7 (28.3) and 31.8 (31.8) points, respectively. Using Q4 of 1999 as the base quarter and comparing later quarters to this base quarter, we find much larger increases in both the nominal and effective yield spreads (all significant at $p<0.01$ ), peaking in Q2 of 2001 ( 93.5 points for the nominal and 87.0 points for the effective yield spreads, respectively). A comparison on the two grand means for mortgage corporations shows the nominal (effective) yield spreads rose 41.0 (35.4) basis points in the post-GST periods (significant at $p<0.01$ ).

\subsection{Regression Results}

To test the effect of the GST on mortgage costs in a more precise way, we conduct a series of pooled cross-sectional regression analyses using monthly data. The dependent variable for the model is the monthly yield spreads and the independent variables are the GST as a dummy variable, credit criteria (including loan to value ratios and loan size), a market default risk factor and seasonal effect variables.

Table 4 presents the regression results on nominal yield spreads (Panel A) and effective yield spreads (Panel B). The models for both nominal and effective yield spreads have achieved significant regression results with $F$-statistics $(56.3, p<0.001)$ and adjusted $R^{2}(0.43)$ for the nominal yield spreads, and $F$-statistics $(46.4, p<0.001)$ and adjusted $R^{2}$ $(0.39)$ for the effective yield spreads.

The regression results (table 4) show that, after controlling other variables, the GST alone increased the nominal and effective yield spreads by 56.3 and 50.5 basis points, respectively (both significant at $p<0.01$ ), indicating that the GST contributed significantly to the rise in mortgage costs in the periods examined. The results for the loan to value variable show that, when controlling the MAXLTV 95 group (maximum LTV $>90 \%$ ), MAXLTV $90(90 \% \geq$ maximum LTV $\geq 85 \%$ ) has significantly $(p<0.01)$ narrower yield spreads (with negative coefficients) for both types of spreads, which are consistent with the predicted signs. However, MAXLTV 85 (maximum LTV $<85 \%$ ) show no significant results, although the sign for the effective yield spreads is as predicted. With respect to loan size, when controlling MAXLOAN100 (A $\$ 1,000,000>$ maximum loans $\geq$ A $\$ 500,000)$, larger loans MAXLOAN200 (maximum loans $\geq \mathrm{A} \$ 1,000,000$ ) have higher yield spreads (significant at $p<0.05$ ) while smaller loans MAXLOAN50 (maximum loans $<$ A $\$ 500,000$ ) have lower yield spreads (significant $p<0.01$ ), which indicates that larger (smaller) loans are considered riskier (less risky) by the lender and the yield spreads charged by the lender are adjusted accordingly. These findings are generally consistent with prior research examining the relations between lending criteria and mortgage yield spreads (e.g., Hendershott and Shilling, 1989; Ambrose et al., 2004; Liu and 
Skully, 2005). The market default risk variable (MDFT) and seasonal effects (either monthly or quarterly) for mortgage corporations are significant at different levels for both nominal and effective yield spreads.

To ensure the validity of the results, for all the regression analyses conducted we also check colinearity problems among the explanatory variables by testing their variance inflating factor (VIF). According to Studenmund (2001), regression results would have colinearity problems if explanatory variables have VIF of 5 or above. As shown in table 4, all VIF are less than 2 (far below 5), suggesting that colinearity problems among the variables are not substantial and, therefore, the regression results should remain valid.

\section{Conclusion}

Using both monthly and quarterly mortgage data of Australian mortgage corporations that covers 36 months from January 1999 to December 2001, this study empirically examines the changes of mortgage yield spreads and quantitatively measures the impact of the GST on mortgage costs for the research period. The results of this study show that the introduction of the GST in July 2000 has had a significant impact on mortgage yield spreads and has contributed to the substantial rise in mortgage costs charged by mortgage corporations in the post-GST periods. This finding is in general consistent with that of prior studies on the impact of the GST on the price of goods and services.

However, this study (and the studies by the same authors on the same issue) is unique in that it examines the GST impact on a special type of financial service, housing mortgage. With respect to the research findings, unlike prior studies on price levels which conclude that the GST effect was only a one-off price perturbation in the quarter of the introduction of the GST (i.e., the third quarter of 2000) and prices did not increase significantly before or after that quarter, this study has the following additional findings. Firstly, the increase in mortgage costs in the third quarter of 2000, as compared to some other quarters, is only minimal. Secondly, mortgage costs of mortgage corporations started to rise significantly in the first and second quarters of 2000, two quarters before the introduction of the GST. Thirdly, mortgage costs continued to rise after the implementation of the GST in the third quarter of 2000. In fact, in the 6 post-GST quarters from July 2000 to December 2001, mortgage costs were on the rise in most quarters. This finding clearly shows that the GST impact on mortgage costs charged by Australian mortgage corporations persisted and was not a one-off surge. Finally, the quantitative measures are determined on the effects of the GST on mortgage costs for the 12 quarters or 36 months investigated. The results of $t$-tests based on quarterly data show that mortgage corporations increased their nominal yield spreads by 41.0 basis points and effective yield spreads by 35.4 basis points in the post-GST periods. The regression results based on monthly data show that mortgage corporations increased the nominal yield spreads by 56.3 basis points and the effective yield spreads by 50.5 basis points in the post-GST periods. The increase in mortgage costs has inevitably made a contribution to the decline in housing affordability in Australia.

The empirical results as reported above for mortgage corporations are overall consistent with the results for banks (Huang and Liu, 2012), building societies (Liu and Huang, 2010, 2011) and credit unions (Liu and Huang, 2012) in terms of the increases in basis points of yield spreads in the post-GST periods, albeit the existence of minor variations. This consistency in the results indicates that the financial institutions operating in the Australian mortgage lending market reacted to the GST in their pricing of mortgage loans in a similar manner, regardless of banks or non-bank, profit-oriented or not-for-profit financial institutions.

In the new tax system with the GST, financial institutions and financial products are treated differently from other types of organisations and goods and services. While financial institutions pay GST on the operational supplies they acquire (input GST), no output GST is charged on the financial products they provide. Hence, the input GST is not recoverable as input tax credits and financial institutions are effectively treated as the end-consumer. This GST cost will need to be absorbed by financial institutions first and then be allocated to the products/services (e.g., mortgages) they supply by the way of increasing the overall charges to their customers. Australian mortgage corporations compensate themselves for the additional costs of GST incurred in their business operations by increasing the mortgage yield spreads they charge mortgage loan holders. It is not clear, however, how financial institutions allocate the GST cost among all supplies they provide and, in particular, how they determine the mortgage yield spreads as a result of the GST. It is likely that financial institutions may take the opportunity of implementing the GST to increase the price of their supplies and improve profit margins. As a consequence of this pricing behaviour of the financial institutions and the change of market conditions, the mortgage burdens on Australian borrowers have risen substantially and the housing affordability has declined sharply in the past decade. We have also observed that financial institutions have been reporting record profits in recent years.

The findings of this study should have important financial, economic and policy implications for regulators and policymakers in the financial industry in terms of contemplating the proper regulations and policies to control and 
curb mortgage costs in order to ease the mortgage burdens borne by the Australian borrowers. For the borrowers, the evidence suggests that lenders have passed the GST costs of multi billion dollars on to them each year. For example, for 2001 alone, based on the mortgage balance of A $\$ 353$ billion at the end of June 2001, the mortgage cost could be increased by $\mathrm{A} \$ 1.8$ billion ( $\mathrm{A} \$ 353 \mathrm{~b} * 0.5 \%$ ). For policymakers, in the wake of the recent global financial crisis and in consideration of Australian housing affordability problem (the worst among the surveyed countries), and to help reduce the cost for the lender and borrower, the GST input credit for lenders should be reconsidered. It is also suggested that future research should investigate the GST costs incurred by financial institutions and correlate the GST costs with mortgage yield spreads to determine the pricing behaviour of financial institutions and to provide specific guidance for the policymaking process.

\section{References}

Ambrose, B.W., LaCour-Little, M., \& Sanders, A.B. (2004). The effects of conforming loan status on mortgage yield spreads: A loan level analysis. Real Estate Economics, 32, 541-569. http://dx.doi.org/10.1111/j.1080-8620.2004.00102.x

Australian Competition and Consumer Commission. (2001). Report to the Minister under Section $75 A Z$ of the Trade Practices Act 1974, Canberra.

Australian Competition and Consumer Commission. (2003). GST Final Report: ACCC Oversight of Pricing Responses to the Introduction of the New Tax System, Canberra.

Black, D.G., Garbade, K.D., \& Silber, W.L. (1981). The impact of the GNMA pass-through program on FHA mortgage costs. Journal of Finance, 36, 457-469. http://dx.doi.org/10.1111/j.1540-6261.1981.tb00462.x

Bolton, T., \& Dollery, B. (2005). An empirical note on the comparative macroeconomic effects of the GST in Australia, Canada and New Zealand. Economic Papers, 24, 50-60. http://dx.doi.org/10.1111/j.1759-3441.2005.tb00994.x

Buffini, F. (2000a). Readiness for GST tipped to cost \$24b. Australian Financial Review, 6 January, 6.

Buffini, F. (2000b). \$10bn bill for compliance. Australian Financial Review, 21 January, 59.

Cnossen, S. (2000). Global trends and issues in value added taxation, GST 2000 Australian law and European experience. Conference at the University of Potsdam.

Commonwealth Treasury. (1998). Regulation Impact Statement for the Introduction of a Goods and Services Tax in A New Tax System Bills. Commonwealth Treasury of Australia, Canberra.

Commonwealth Treasury. (2000). Budget speech 2000-01, delivered on 9 May 2000 on the second reading of the Appropriation Bill (no. 1) 2000-01 by the Honourable Peter Costello. Commonwealth Treasury of Australia, Canberra.

Demographoia. (2009). The $5^{\text {th }}$ Annual Demographoia International Housing Affordability Survey 2009, 1-52.

Ebrahim, M.S., \& Mathur, I. (2007). Pricing home mortgages and bank collateral: A rational expectations approach. Journal of Economic Dynamics and Control, 31, 1217-1244. http://dx.doi.org/10.1016/j.jedc.2006.03.007

Ernst and Young. (1999). Preparing for the GST: An Australian Survey.

Hendershott, P.H., \& Shilling, J.D. (1989). The impact of the agencies on conventional fixed-rate mortgage yields. Journal of Real Estate Finance and Economics, 2, 101-115. http://dx.doi.org/10.1007/BF00159793

Huang, A., \& Liu, B. (2012). The impact of the GST on bank mortgage yield spreads in Australia. Applied Financial Economics, 22, 1787-1797. http://dx.doi.org/10.1080/09603107.2012.678980

Johnson, D.T., Freebairn, J., \& Scutella, R. (1999). Evaluation of the Government's Tax Package. Melbourne Institute of Applied Economic and Social Research, University of Melbourne, Melbourne.

Joint Government Advocate, GST Implementation and Compliance Costs, Attachment ID in Letter to the President of the Australian Industrial Relations Commission Bench (31 March 2000).

Kau, J.B. (2005). The effect of mortgage price and default risk on mortgage spreads. Journal of Real Estate Finance and Economics, 30, 285-295. http://dx.doi.org/10.1007/s11146-005-6408-9

Kolari, J.W., Fraser, D.R., \& Anari, A. (1998). The effects of securitisation on mortgage market yields: A cointegration analysis. Real Estate Economics, 26, 667-677. 
Kumar, J., \& Ralston, D. (1999). The growth of mortgage managers and their impact on the Australian home loan market. Accounting Research Journal, 12, 45-53.

Liu, B., \& Huang, A. (2010). The goods and services tax and mortgage costs of Australian building societies. European Journal of Economics, Finance and Administrative Sciences, 25, 109-117.

Liu, B., \& Huang, A. (2011). The impact of the GST on mortgage yield spreads of Australian building societies. Journal of Modern Accounting and Auditing, 7, 986-993.

Liu, B., \& Huang, A. (2012). Goods and services tax and mortgage costs of Australian credit unions. The Empirical Economics Letters, 11, 935-942.

Liu, B., \& Skully, M. (2005). The determinant of mortgage yield spread differentials: securitisation. Journal of Multinational Financial Management, 15, 314-333. http://dx.doi.org/10.1016/j.mulfin.2005.04.003

Liu, B., \& Skully, M. (2008). The impact of securitisation and structural changes of Australian mortgage markets on bank pricing behaviour. International Journal of Banking, Finance and Accounting, 1, 149-167. http://dx.doi.org/10.1504/IJBAAF.2008.020646

Maclntyre, M. (2001). GST and the financial market. Sydney: CCH Australia Limited.

New South Wales Treasury. (2001). 2000-01 Half Yearly Budget Review, NSW Treasury, Sydney.

Queensland Treasury. (2001). CPI Exclusive of GST Effects: June Quarter 2001 (a briefing note). Office of Economic and Statistical Research, Queensland Treasury, Brisbane.

Regulation Impact Statement for the Introduction of a Goods and Services, (2 December 1998), Cat No. 9837341.

Sandford, C.T., Godwin, M.R., \& Hardwick, P.J.W. (1989). Administrative and Compliance Costs of Taxation. Fiscal Publications, Bath.

Studenmund, A.H. (2001). Using econometrics: a practical guide (the $4^{\text {th }}$ ed.). Boston: Addison Wesley Longman.

Tran-Nam, B. (1999). Assessing the revenue and simplification impacts of the government's tax reform. Journal of Australian Taxation, 2, 329-43.

Tran-Nam, B. (2000). The Implementation costs of the GST in Australia: concepts, preliminary estimates and implications. Journal of Australian Taxation, 3, 331-43.

Tran-Nam, B. (2001). Use and misuse of tax compliance costs in evaluating the GST. The Australian Economic Review, 34, 279-90.

Valadkhani, A., \& Layton, A.P. (2004). Quantifying the effect of GST on inflation in Australia's capital cities: An intervention analysis. Australian Economic Review, 37, 125-138.

Valadkhani, A. (2005). Goods and services tax effects on goods and services included in the consumer price index basket. The Economic Record, 81, 104-14.

Warren, N., Harding, A., Robinson, M., Lambert, S., \& Beer, G. (1999). Distributional impact of possible tax reform packages, report to senate select committee on a new tax system. National Centre for Social and Economic Modelling (NATSEM), University of Canberra, Canberra.

\section{Notes}

Note 1. The reason for this unique treatment of financial institutions is said to be the difficulty in quantifying the service charge included in moneys earned by financial institution. As Cnossen (2000) explains, conventional wisdom holds that financial services cannot be included in the GST base calculated on the tax credit method, because the intermediation charge that should be taxed cannot be separated from the pure interest rate, premium or rate of return that should not be taxed. Therefore, it is considered unavoidable that financial services should be exempted from GST.

Note 2. Considering the length of the paper, we exclude the descriptive statistics of the data from the paper.

Note 3. More information about the AAPR calculations is available on CANNEX website www.cannex.com.au

Appendix 1. Mortgage corporations operating in Australia for the research period

\begin{tabular}{lll}
\hline A M O Group & Direct Home Loans & MLCompany Pty Ltd \\
AAA Mortgage Solutions & Eurofinance Corporation & Mortgage House of Aust
\end{tabular}


Access Home Loans

ACE Home Loans

AIMS Home Loans

AM Mortgage Plus

API Lifestyle Home Loans

Aussie Home Loans

Austral Mortgage

AXA Home Loans

Better Choice Home Loans

BMC Mortgage

CHS Home Loans

Collins Securities
FAI Home Loans

Future Mortgage Corp

Grenfell Securities

Homeloans NSW

Homeloans Plus

Homeloans QLD

HomePath

La Trobe Home Loans Aust

LJ Hooker Home Loans

LoanNET

Locumsgroup
MY ELOAN

Nationwide Mortgage Corp

Pacific Mortgage Corp

RAMS Mortgage Corp

RESI Mortgage Corp

Royal Guardian Mortgage

WA Home Loans

Wizard Mortgage Corp

Yes Home Loans

Source: Cannex of Australia.

Table 1. Definition and predicted signs of variables in equations 1 and 2

\begin{tabular}{|c|c|c|c|}
\hline Variable & Definition & Predicted & Signs \\
\hline \multicolumn{2}{|c|}{$\begin{array}{l}\text { Panel A: Dependent variables } \\
\text { Equations }\end{array}$} & (1) & $(2)$ \\
\hline NYSP & $\begin{array}{l}\text { Nominal yield spreads = standard adjustable interest rates over } \\
90 \text {-day bill rates } \\
\text { Effective yield spreads = sum of standard adjustable interest } \\
\text { rates and all other } \\
\text { fees and charges on mortgage over 90-day bill rates }\end{array}$ & NYSP & EYSP \\
\hline \multicolumn{4}{|c|}{ Panel B: Independent variables } \\
\hline GST & Dummy variable, pre-July $2000=0$; otherwise $=1$ & $\alpha_{1}(+)$ & $\beta_{1}(+)$ \\
\hline MAXLTV90 & $90 \% \geq$ maximum loan to value ratio $\geq 85 \%$ & $\alpha_{3}(-)$ & $\beta_{3}(-)$ \\
\hline MAXLTV85 & Maximum loan to value ratio $<85 \%$ & $\alpha_{4}(-)$ & $\beta_{4}(-)$ \\
\hline MAXLOAN200 & Maximum loans $\geq A \$ 1000000$ & $\alpha_{5}(+)$ & $\beta_{5}(+)$ \\
\hline MAXLOAN50 & Maximum loans $<\mathrm{A} \$ 500000$ & $\alpha_{7}(-)$ & $\beta_{7}(-)$ \\
\hline$M A X N O$ & $\begin{array}{l}\text { No maximum loans required by the lender } \\
\text { Yield differences between AAA- and A-rated cornorate bonds }\end{array}$ & $\alpha_{8}(+)$ & $\beta_{8}(+)$ \\
\hline$M D F T$ & $\begin{array}{l}\text { with a 2-4 year } \\
\text { constant maturity, proxing the market condition }\end{array}$ & $\alpha_{9}(-)$ & $\beta_{9}(-)$ \\
\hline Mon 1 & January each year from 1999 to 2001 & $\xi_{1}(+)$ & $\omega_{1}(+)$ \\
\hline Mon 2 & February each year from 1999 to 2001 & $\xi_{2}(+)$ & $\omega_{2}(+)$ \\
\hline Mon 3 & March each year from 1999 to 2001 & $\xi_{3}(+)$ & $\omega_{3}(+)$ \\
\hline Mon 4 & April each year from 1999 to 2001 & $\xi_{4}(+)$ & $\omega_{4}(+)$ \\
\hline Mon 5 & May each year from 1999 to 2001 & $\xi_{5}(+)$ & $\omega_{5}(+)$ \\
\hline Mon 6 & June each year from 1999 to 2001 & $\xi_{6}(+)$ & $\omega_{6}(+)$ \\
\hline Mon 7 & July each year from 1999 to 2001 & $\xi_{7}(+)$ & $\omega_{7}(+)$ \\
\hline Mon 9 & September each year from 1999 to 2001 & $\xi_{9}(+)$ & $\omega_{9}(+)$ \\
\hline Mon 10 & October each year from 1999 to 2001 & $\xi_{10}(+)$ & $\omega_{10}(+)$ \\
\hline Mon 11 & November each year from 1999 to 2001 & $\xi_{11}(+)$ & $\omega_{11}(+)$ \\
\hline Mon 12 & December each year from 1999 to 2001 & $\xi_{12}(+)$ & $\omega_{12}(+)$ \\
\hline Qut 1 & The first quarter each year from 1999 to 2001 & $\phi_{1}(+)$ & $\lambda_{1}(+)$ \\
\hline Qut 2 & The second quarter each year from 1999 to 2001 & $\phi_{2}(+)$ & $\lambda_{2}(+)$ \\
\hline Qut 4 & The fourth quarter each from 1999 to 2001 & $\phi_{4}(+)$ & $\lambda_{4}(+)$ \\
\hline \multicolumn{4}{|c|}{ Panel C: Control variables } \\
\hline MAXLTV95 & Maximum loan to value ratio $>90 \%$ & $\alpha_{2}$ & $\beta_{2}$ \\
\hline MAXLOAN100 & $\mathrm{A} \$ 1000000>$ maximum loans $\geq \mathrm{A} \$ 500000$ & $\alpha_{6}$ & $\beta_{6}$ \\
\hline Mon 8 & August each year from 1999 to 2001 & $\xi_{8}$ & $\omega_{8}$ \\
\hline Qut 3 & The third quarter each year from 1999 to 2001 & $\phi_{3}$ & $\lambda_{3}$ \\
\hline
\end{tabular}


Table 2. Mortgage corporation nominal yield spread differentials: matrix of $t$-tests using quarterly means*

\begin{tabular}{|c|c|c|c|c|c|c|c|c|c|c|c|c|c|c|}
\hline \multirow{5}{*}{1999} & \multicolumn{5}{|c|}{1999} & \multicolumn{3}{|c|}{2000} & \multicolumn{5}{|c|}{2001} & \multirow[b]{2}{*}{ Pre GST } \\
\hline & $\mathrm{Q} 1 \uparrow$ & $\begin{array}{c}\mathrm{Q} 1 \\
0.000\end{array}$ & Q2 & Q3 & Q4 & Q1 & Q2 & Q3 & Q4 & Q1 & Q2 & Q3 & Q4 & \\
\hline & $\mathrm{Q} 2 \uparrow$ & $(0.104)^{b}$ & 0.000 & & & & & & & & & & & \\
\hline & 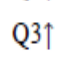 & $(0.194)^{\mathrm{a}}$ & $(0.090)^{b}$ & 0.000 & & & & & & & & & & \\
\hline & $\mathrm{Q} 4 \uparrow$ & $(0.600)^{\mathrm{a}}$ & $(0.497)^{\mathrm{a}}$ & $(0.406)^{\mathrm{a}}$ & 0.000 & & & & & & & & & \\
\hline 2000 & $\mathrm{Q} 1 \uparrow$ & $(0.323)^{\mathrm{a}}$ & $(0.220)^{\mathrm{a}}$ & $(0.129)^{\mathrm{a}}$ & $0.277^{\mathrm{a}}$ & 0.000 & & & & & & & & \\
\hline & $\mathrm{Q} 2 \uparrow$ & $(0.284)^{\mathrm{a}}$ & $(0.178)^{\mathrm{a}}$ & $(0.088)^{b}$ & $0.318^{\mathrm{a}}$ & 0.041 & 0.000 & & & & & & & \\
\hline & 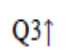 & $(0.228)$ & $(0.125)^{a}$ & $(0.350)$ & $0.371^{a}$ & $0.940^{b}$ & 0.116 & 0.000 & & & & & & \\
\hline & $\mathrm{Q} 4 \uparrow$ & 0.037 & $0.140^{\mathrm{a}}$ & $0.230^{\mathrm{a}}$ & $0.637^{\mathrm{a}}$ & $0.360^{\mathrm{a}}$ & $0.319^{\mathrm{a}}$ & $0.265^{\mathrm{a}}$ & 0.000 & & & & & \\
\hline 2001 & $\mathrm{Q} 1 \uparrow$ & $0.249^{\mathrm{a}}$ & $0.352^{\mathrm{a}}$ & $0.443^{\mathrm{a}}$ & $0.849^{\mathrm{a}}$ & $0.572^{\mathrm{a}}$ & $0.531^{2}$ & $0.478^{\mathrm{a}}$ & $0.212^{\mathrm{a}}$ & 0.000 & & & & \\
\hline & $\mathrm{Q} 2 \uparrow$ & $0.335^{\mathrm{a}}$ & $0.439^{\mathrm{a}}$ & $0.529^{\mathrm{a}}$ & $0.935^{\mathrm{a}}$ & $0.658^{\mathrm{a}}$ & $0.617^{\mathrm{a}}$ & $0.564^{2}$ & $0.299^{\mathrm{a}}$ & $0.086^{\mathrm{b}}$ & 0.000 & & & \\
\hline & Q3个 & $0.142^{\mathrm{a}}$ & $0.246^{a}$ & $0.336^{\mathrm{a}}$ & $0.743^{\mathrm{a}}$ & $0.466^{\mathrm{a}}$ & $0.424^{2}$ & $0.371^{\mathrm{a}}$ & $0.106^{b}$ & $0.106^{\mathrm{a}}$ & $(0.193)^{\mathrm{a}}$ & 0.000 & & \\
\hline & $\mathrm{Q} 4 \uparrow$ & $0.324^{\mathrm{a}}$ & $0.427^{\mathrm{a}}$ & $0.518^{\mathrm{a}}$ & $0.924^{\mathrm{a}}$ & $0.467^{\mathrm{a}}$ & $0.606^{\mathrm{a}}$ & $0.553^{\mathrm{a}}$ & $0.287^{\mathrm{a}}$ & $0.075^{b}$ & $(0.011)$ & $0.181^{a}$ & 0.000 & \\
\hline Post GST & & & & & & & & & & & & & & $0.410^{\mathrm{a}}$ \\
\hline No. of obs. & & 91 & 98 & 99 & 103 & 108 & 112 & 115 & 119 & 111 & 138 & 127 & 131 & 1354 \\
\hline
\end{tabular}

${ }^{*}$ A quarter to quarter comparison is made from the left to the top, as the arrow signs indicate. The value in parentheses is negative.

a, b denote the $1 \%$ and $5 \%$ levels of significance, respectively.

Table 3. Mortgage corporation effective yield spread differentials: matrix of $t$-tests using quarterly means*

\begin{tabular}{|c|c|c|c|c|c|c|c|c|c|c|c|c|c|c|}
\hline \multirow{6}{*}{1999} & \multicolumn{5}{|c|}{1999} & \multicolumn{3}{|c|}{2000} & \multicolumn{5}{|c|}{2001} & \multirow[b]{2}{*}{ Pre GST } \\
\hline & & Q1 & Q2 & Q3 & Q4 & Q1 & Q2 & Q3 & Q4 & Q1 & Q2 & Q3 & Q4 & \\
\hline & Q1 $\uparrow$ & 0.000 & & & & & & & & & & & & \\
\hline & $\mathrm{Q} 2 \uparrow$ & $(0.113)^{\mathrm{b}}$ & 0.000 & & & & & & & & & & & \\
\hline & $\mathrm{Q} 3 \uparrow$ & $(0.201)^{\mathrm{a}}$ & $(0.088)^{b}$ & 0.000 & & & & & & & & & & \\
\hline & $\mathrm{Q} 4 \uparrow$ & $(0.601)^{\mathrm{a}}$ & $(0.493)^{\mathrm{a}}$ & $(0.404)^{\mathrm{a}}$ & 0.000 & & & & & & & & & \\
\hline 2000 & Q1 $\uparrow$ & $(0.321)^{\mathrm{a}}$ & $(0.210)^{\mathrm{a}}$ & $(0.121)^{\mathrm{a}}$ & $0.283^{\mathrm{a}}$ & 0.000 & & & & & & & & \\
\hline & $\mathrm{Q} 2 \uparrow$ & $(0.286)^{\mathrm{a}}$ & $(0.175)^{\mathrm{a}}$ & $(0.086)^{b}$ & $0.318^{\mathrm{a}}$ & 0.035 & 0.000 & & & & & & & \\
\hline & Q3个 & $(0.234)^{\mathrm{a}}$ & $(0.122)^{\mathrm{a}}$ & $(0.033)$ & $0.371^{\mathrm{a}}$ & $0.088^{b}$ & 0.053 & 0.000 & & & & & & \\
\hline & $\mathrm{Q} 4 \uparrow$ & $(0.037)$ & $0.071^{c}$ & $0.165^{\mathrm{a}}$ & $0.569^{\mathrm{a}}$ & $0.286^{\mathrm{a}}$ & $0.251^{\mathrm{a}}$ & $0.178^{\mathrm{a}}$ & 0.000 & & & & & \\
\hline 2001 & $\mathrm{Q} 1 \uparrow$ & $0.173^{\mathrm{a}}$ & $0.288^{\mathrm{a}}$ & $0.377^{\mathrm{a}}$ & $0.781^{\mathrm{a}}$ & $0.498^{\mathrm{a}}$ & $0.463^{\mathrm{a}}$ & $0.410^{\mathrm{a}}$ & $0.212^{\mathrm{a}}$ & 0.000 & & & & \\
\hline & $\mathrm{Q} 2 \uparrow$ & $0.262^{\mathrm{a}}$ & $0.378^{\mathrm{a}}$ & $0.466^{\mathrm{a}}$ & $0.870^{\mathrm{a}}$ & $0.587^{\mathrm{a}}$ & $0.552^{\mathrm{a}}$ & $0.499^{\mathrm{a}}$ & $0.301^{a}$ & $0.089^{b}$ & 0.000 & & & \\
\hline & 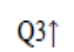 & $0.072^{b}$ & $0.186^{\mathrm{a}}$ & $0.275^{\mathrm{a}}$ & $0.679^{\mathrm{a}}$ & $0.396^{\mathrm{a}}$ & $0.361^{\mathrm{a}}$ & $0.308^{\mathrm{a}}$ & $0.110^{\mathrm{a}}$ & $0.102^{\mathrm{a}}$ & $(0.191)^{\mathrm{a}}$ & 0.000 & & \\
\hline & $\mathrm{Q} 4 \uparrow$ & $0.253^{\mathrm{a}}$ & $0.369^{\mathrm{a}}$ & $0.457^{\mathrm{a}}$ & $0.861^{a}$ & $0.578^{\mathrm{a}}$ & $0.543^{\mathrm{a}}$ & $0.490^{\mathrm{a}}$ & $0.292^{\mathrm{a}}$ & $0.080^{b}$ & $(0.033)$ & $(0.183)^{\mathrm{a}}$ & 0.000 & \\
\hline Post GST & & & & & & & & & & & & & & $0.354^{\mathrm{a}}$ \\
\hline No. of Obs. & & 91 & 98 & 99 & 103 & 108 & 112 & 115 & 119 & 111 & 138 & 127 & 131 & 1354 \\
\hline
\end{tabular}


Table 4. Regression relating mortgage corporation yield spreads to GST, credit criteria, seasons and market default risk

\begin{tabular}{|c|c|c|c|c|c|c|}
\hline \multirow[b]{2}{*}{ Explanatory Variables } & \multicolumn{3}{|c|}{$\begin{array}{l}\text { Panel A* } \\
\text { Nominal Yield Spreads (NYSP) }\end{array}$} & \multicolumn{3}{|c|}{$\begin{array}{l}\text { Panel B* } \\
\text { Effective Yield Spreads (EYSP) }\end{array}$} \\
\hline & Coefficient & $t$-statistic & VIF & Coefficient & $t$-statistic & VIF \\
\hline Intercept & 1.408 & $23.297^{\mathrm{a}}$ & $\sim$ & 1.528 & $25.125^{\mathrm{a}}$ & $\sim$ \\
\hline GST & 0.563 & $27.925^{\mathrm{a}}$ & 1.536 & 0.505 & $24.878^{\mathrm{a}}$ & 1.536 \\
\hline MAXLTV90 & $(0.108)$ & $(5.580)^{\mathrm{a}}$ & 1.257 & $(0.116)$ & $(5.967)^{\mathrm{a}}$ & 1.257 \\
\hline MAXLTV85 & 0.007 & 0.104 & 1.061 & $(0.016)$ & $(0.241)$ & 1.061 \\
\hline MAXLOAN200 & 0.045 & $2.321^{\mathrm{b}}$ & 1.410 & 0.049 & $2.503^{\mathrm{b}}$ & 1.410 \\
\hline MAXLOAN50 & $(0.095)$ & $(3.401)^{\mathrm{a}}$ & 1.208 & $(0.104)$ & $(3.700)^{\mathrm{a}}$ & 1.208 \\
\hline MAXNO & $(0.014)$ & $(0.426)$ & 1.132 & $(0.036)$ & $(1.058)$ & 1.132 \\
\hline MDFT & $(0.013)$ & $(9.690)^{\mathrm{a}}$ & 1.597 & $(0.013)$ & $(9.391)^{\mathrm{a}}$ & 1.597 \\
\hline \multicolumn{7}{|l|}{ Month Effects: } \\
\hline Mon 1 & 0.149 & $3.606^{\mathrm{a}}$ & 1.791 & 0.131 & $3.151^{\mathrm{a}}$ & 1.791 \\
\hline Mon 2 & 0.346 & $8.484^{\mathrm{a}}$ & 1.846 & 0.329 & $7.998^{\mathrm{a}}$ & 1.846 \\
\hline Mon 3 & 0.295 & $7.227^{\mathrm{a}}$ & 1.814 & 0.276 & $6.704^{\mathrm{a}}$ & 1.814 \\
\hline Mon 4 & 0.413 & $10.368^{\mathrm{a}}$ & 1.911 & 0.391 & $9.742^{\mathrm{a}}$ & 1.911 \\
\hline Mon 5 & 0.308 & $7.683^{\mathrm{a}}$ & 1.929 & 0.285 & $7.057^{\mathrm{a}}$ & 1.929 \\
\hline Mon 6 & 0.342 & $8.528^{\mathrm{a}}$ & 1.929 & 0.317 & $7.850^{\mathrm{a}}$ & 1.929 \\
\hline Mon 7 & 0.113 & $2.870^{\mathrm{a}}$ & 1.833 & 0.109 & $2.749^{\mathrm{a}}$ & 1.833 \\
\hline Mon 9 & 0.071 & 1.787 & 1.843 & 0.067 & 1.696 & 1.843 \\
\hline Mon 10 & 0.148 & $3.691^{\mathrm{a}}$ & 1.880 & 0.123 & $3.047^{\mathrm{a}}$ & 1.880 \\
\hline Mon 11 & 0.139 & $3.499^{\mathrm{a}}$ & 1.937 & 0.113 & $2.823^{\mathrm{a}}$ & 1.937 \\
\hline Mon 12 & 0.223 & $5.605^{\mathrm{a}}$ & 1.907 & 0.198 & $4.932^{\mathrm{a}}$ & 1.907 \\
\hline \multicolumn{7}{|l|}{ Quarter Effects: } \\
\hline Qut 1 & 0.204 & $8.270^{\mathrm{a}}$ & 1.592 & 0.188 & $7.573^{\mathrm{a}}$ & 1.592 \\
\hline Qut 2 & 0.295 & $12.213^{\mathrm{a}}$ & 1.662 & 0.274 & $11.269^{\mathrm{a}}$ & 1.662 \\
\hline Qut 4 & 0.111 & $4.654^{\mathrm{a}}$ & 1.625 & 0.088 & $3.665^{\mathrm{a}}$ & 1.625 \\
\hline No. of observations & 1344 & & & 1344 & & \\
\hline Adjusted R-square & 0.425 & & & 0.387 & & \\
\hline$F$-statistic & 56.289 & & & 46.423 & & \\
\hline$p$-value & 0.000 & & & 0.000 & & \\
\hline
\end{tabular}

* We control the variables: MAXLTV95, MAXLOAN100, August and the third quarter as the reference in each regression analysis.

a, $b$ denote the $1 \%$ and $5 \%$ levels of significance, respectively. The value in parentheses is negative. 